\title{
BLOOD COUNT AND C-REACTIVE PROTEIN EVOLUTION IN GASTRIC CANCER PATIENTS WITH TOTAL GASTRECTOMY SURGERY
}

\author{
Evolução do hemograma e proteína C-reativa em pacientes com câncer gástrico operados por gastrectomia total
}

Attila CSENDES J.2, Andrea MUÑOZ Ch. ${ }^{1}$, Ana María BURGOS L. ${ }^{2}$

From the ${ }^{1}$ Capacitating Medical Doctor, Department of Surgery, Universidad de Chile Clinical Hospital and ${ }^{2}$ Department of Surgery, Universidad de Chile Clinical Hospital, Santiago, Chile
ABSTRACT - Background: The complete blood count (CBC) and C-reactive protein (CRP) are useful inflammatory parameters for ruling out acute postoperative inflammatory complications. Aim:To determine their changes in gastric cancer patients submitted to total gastrectomy. Methods: This is a prospective study, with 36 patients with gastric cancer who were submitted to elective total gastrectomy. On the first, third and fifth postoperative day (POD), blood count and CRP changes were assessed. Patients with postoperative complications were excluded. Results: Twenty-one (58\%) were men and 15 (42\%) women. The mean age was 65 years. The leukocytes peaked on the $1^{\text {st }}$ POD with a mean of $13,826 \mathrm{u} / \mathrm{mm}^{3}$, and decreased to $8,266 \mathrm{u} / \mathrm{mm}^{3}$ by the $5^{\text {th }}$ POD. The bacilliforms peaked on the $1^{\text {st }}$ POD with a maximum value of $1.48 \%$. CRP reached its maximum level on the $3^{\text {rd }}$ POD with a mean of $144.64 \mathrm{mg} / \mathrm{l} \pm 44.84$. Preoperative hematocrit (HCT) was $35 \%$ and $33.67 \%$ by the $5^{\text {th }}$ POD. Hemoglobin, showed similar values. Conclusions: Leukocytes increased during the $1^{\text {st }}$ POD but reached normal values by the $5^{\text {th }} P O D$. CRP peaked on the $3^{\text {rd }} P O D$ but did not reach normal values by the $5^{\text {th }}$ POD.
HEADINGS - Complete blood count CRP. Cancer neoplasm. Surgery. Total gastrectomy.
RESUMO - Racional: O hemograma completo $(C B C)$ e a proteína C-reativa $(P C R)$ são úteis para excluir parâmetros inflamatórios e complicações inflamatórias agudas pósoperatórias. Objetivo: Determinar mudanças nesses parâmetros em pacientes com câncer gástrico submetidos à gastrectomia total. Métodos: Estudo prospectivo com 36 pacientes com câncer gástrico submetidos todos à gastrectomia eletiva. No primeiro, terceiro e quinto dias pós-operatórios (PO), alterações do hemograma e as mudanças de PCR foram avaliadas. Os pacientes com complicações pós-operatórias foram excluídos. Resultados: Vinte e um (58\%) eram homens e 15 (42\%) mulheres. A média de idade era de 65 anos. Os leucócitos atingiram o pico no primeiro PO com média de $13.826 \mathrm{u} / \mathrm{mm}^{3}$, e decresceram para $8.266 \mathrm{u} / \mathrm{mm}^{3}$ no quinto. Os bastonetes atingiram o pico no primeiro PO com valor máximo de $1,48 \%$. O nível máximo da $\mathrm{PCR}$ foi no $3^{\circ} \mathrm{PO}$, com média de $144,64 \mathrm{mg} / \mathrm{l} \pm 44,84$. O hematócrito pré-operatório (HCT) foi de $35 \%$ e de $33,67 \%$ até o $5^{\circ} \mathrm{PO}$. A hemoglobina não apresentou alterações. Conclusões: Houve aumento de leucócitos no $1^{\circ} \mathrm{PO}$ mas atingiram valores normais até o $5^{\circ} \mathrm{PO}$. PCR atingiu o pico no $3^{\circ} \mathrm{PO}$, mas não atingiu os valores normais até o quinto.
DESCRTORES - Hemograma completo. CRP. Neoplasia gástrica. Câncer. Cirurgia. Gastrectomia total.

\section{INTRODUCTION}

C -reactive protein (CRP) was first described by Tillet and Francis in 1930 as an acute stage protein in the serum of patients diagnosed with pneumonia ${ }^{1-2}$. With certain stimuli, activated macrophages produce interleukin 6 , which induces CRP synthesis on a hepatic level|-4. CRP is a good parameter for postoperative assessment since it presents a sharp increase in plasma levels immediately after surgery. Its values increase during the first six hours after tissue damage, peak during the second or third postoperative day (POD) and progressively decrease as of this time to reach normal values within the first 30 days after surgery ${ }^{1}$. If complications do not arise, this parameter decreases rapidly and therefore, not only does it allow an inflammatory reaction to be detected but it also allows for its quantification, diagnosis as well as assess its evolution, thus being an excellent evaluation method ${ }^{5}$.

The objective of this study was to determine the evolution that occurs in blood count and C-reactive protein plasma levels in patients diagnosed with gastric cancer submitted to an elective total gastrectomy on the first, third and $5^{\text {th }}$ POD and who have not presented complications.

\section{METHODS}

\section{Patients}

This prospective study was conducted at the Department of Surgery at the Universidad de Chile Clinical Hospital, between January 2009 and April 2013, with 
36 patients diagnosed with gastric cancer submitted to an elective total gastrectomy. Patients with post-operative complications were excluded. A CBC and CRP were done before surgery and again on the $1^{\text {st }}, 3^{\text {th }}$ and $5^{\text {th }}$ POD.

\section{Blood analysis}

The white blood cells or leukocytes were determined using the impedance and $A B X$ Pentra 80 blood analysis cytometry method, with 4,000 to 10,000 leukocytes per cubic millimeter considered as normal values. After obtaining the value for white blood cells, these were analyzed in order to determine the percentage of each cell type. The segmented neutrophils have normal values ranging from $60 \%$ to $70 \%$. Bacilliforms have a range of $0 \%$ to $3 \%$.

In order to determine the serum C-reactive protein level, all samples were measured using the enzyme immunoassay method with a VITROS ${ }^{\circledR} 5.1$ FS Chemical System, with normal values ranging from 0 to $10 \mathrm{mg} / \mathrm{l}$.

\section{Surgical technique}

All patients were submitted to a total gastrectomy with complete removal of the stomach, including a segment of the abdominal esophagus and $2 \mathrm{~cm}$ of the duodenum, as well as with major and minor omentectomy and D2 lymph node dissection. Esophagojeujunal reconstruction was performed with a $70 \mathrm{~cm}$ Roux-en-Y loop using a $25 \mathrm{~mm}$ circular stapler (Covidien, USA). The intestinal anastomosis at the base of the Roux-en-Y loop was performed with manual sutures ${ }^{6}$.

\section{Statistics}

The statistical analysis was done using the Microsoft Excel Program and Statistical Package for Social Sciences (SPSS) 19 , considering $p<0.05$ as significant.

\section{RESULTS}

Out of 36 patients diagnosed with gastric cancer submitted to a total gastrectomy, and who did not present postoperative complications, 21 (58\%) were men and 15 (42\%) women. The mean age was $65 \pm 3.5$ years (31-85). CBC and CRP were taken on the $1^{\text {st }}, 3^{\text {th }}$ and $5^{\text {th }} P O D$, considering the preoperative values (Table 1 ).

TABELA 1 - Inflammatory parameters before and after a total gastrectomy

\begin{tabular}{|c|c|c|c|c|}
\hline & PREOPERATIVE & \multicolumn{3}{c|}{ POSTOPERATIVE } \\
\hline & & First day & Third day & Fifth day \\
\hline $\begin{array}{c}\text { LEUKOCYTES } \\
\left(\mathrm{u} / \mathrm{mm}^{3}\right)\end{array}$ & $8,344.12$ & $13,826.88$ & $10,006.67$ & $8,266.88$ \\
\hline $\begin{array}{c}\text { NEUTROPHILS } \\
(\%)\end{array}$ & 70.59 & 81.03 & 76.21 & 70.55 \\
\hline CRP $(\mathrm{mg} / \mathrm{l})$ & 10.5 & 95.7 & 144.64 & 103.54 \\
\hline
\end{tabular}

Leukocytes peaked on the $1^{\text {st }}$ POD with an average of $13,826 \mathrm{u} / \mathrm{mm}^{3} \pm 4667.82 \mathrm{u} / \mathrm{mm}^{3}$, presenting a significant difference $(p<0.01)$ with the preoperative leukocyte values. Five days after surgery, the white blood cell count was similar to preoperative values $(p>0.8)$. Figure 1 shows the evolution of the white blood cells. The bacilliforms peaked on the $1^{\text {st }}$ day with a maximum value of $1.48 \%$. When analyzing the neutrophils, no significant difference was observed when compared to the five day period after surgery (Figure 2). The preoperative hematocrit was $35 \%$, and on the $5^{\text {th }}$ POD $33.67 \%$ $(p>0.5)$. Similar hemoglobin values persisted over the five day period.

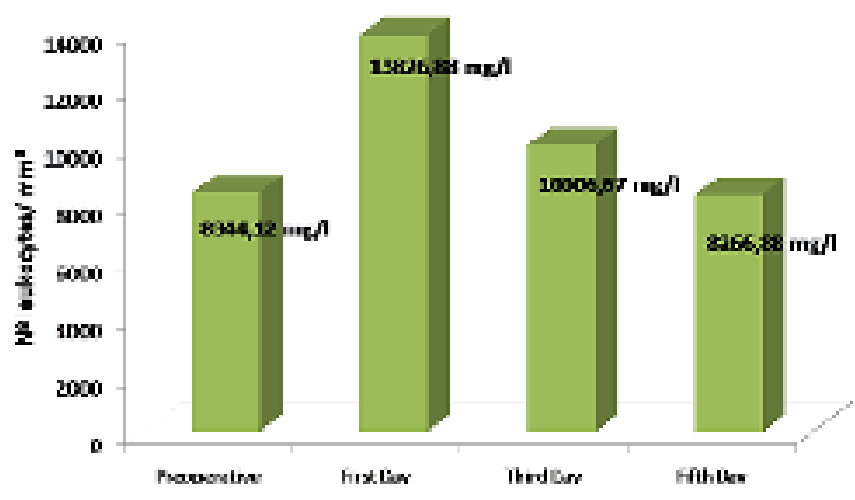

FIGURE 1 - Evolution of leukocyte values during different post-operative periods

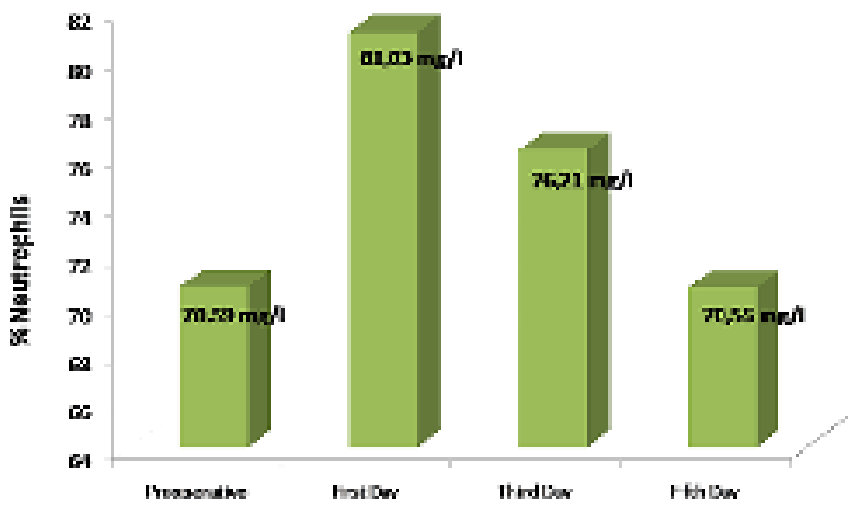

FIGURE 2 - Evolution of neutrophil values during different post-operative periods

CRP increased significantly on the $1^{\text {st }} P O D(p<0.001)$ and peaked on the $3^{\text {rd }}$ POD with an average of $144.64 \mathrm{mg} / \mathrm{l} \pm 44.84$, significantly more than the other days $(p<0.001)$. By the $5^{\text {th }}$ day after surgery, CRP values were similar to the $1^{\text {st }} P O D$ but were still not normal. Figure 3 shows CRP evolution during the postoperative phase.

None of the patients presented complications during or after surgery.

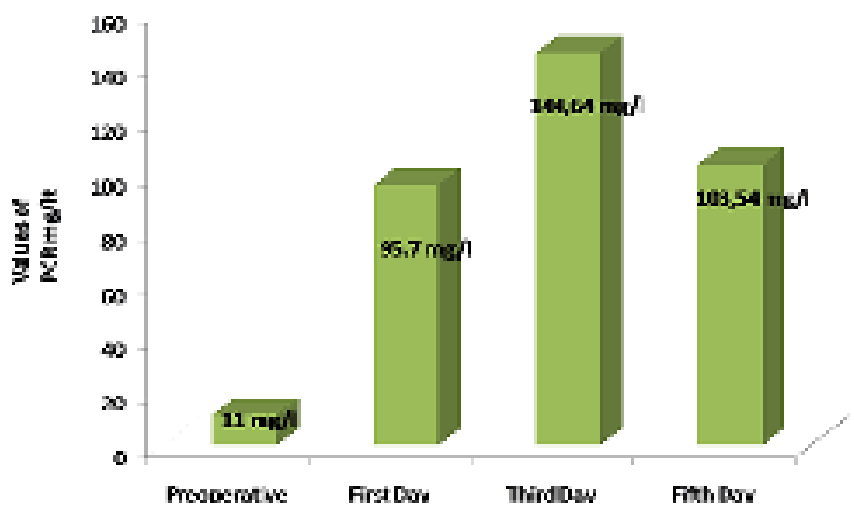

FIGURE 3 - Evolution of C-reactive protein values during different post-operative periods

\section{DISCUSSION}

In Chile, gastric cancer is the leading cause of death due to malignant tumors in both sexes, and the second highest cause of death on a global scale. Chile has one of the highest gastric cancer rates along with Japan, Costa Rica and Singapore ${ }^{7}$. Gastric cancer generally corresponds to adenocarcinoma and is predominantly found in males, with a male/female ratio of $2.6: 1$. The most affected age groups 
are people in their 70's or 80's, with an average of 65 years ${ }^{7}$. Total gastrectomy is the most widely used method for gastric cancer therapy with an operative mortality of $2.1 \%{ }^{6}$. It is usually performed for lesions located in the proximal or middle part of the stomach and for Lauren diffuse-type tumors, while distal subtotal gastrectomy (with resection of adjacent lymph nodes) seems to be sufficient for distal lesions (inferior two thirds) of the stomach. This surgery offers a more promising long term survival rate for patients with localized gastric cancer and even more so when combined with chemotherapy, or perioperative or adjuvant chemoradiotherapy ${ }^{6,8,9}$.

In the present study, the results suggest that total gastrectomy is followed by a physiological inflammatory process due to surgical stress, which can be seen in white blood cell and C-reactive protein values. Polymorphonuclear concentrations increased immediately after surgery, peaked on the $1^{\text {st }} P O D$, and then began to gradually decrease. Another study conducted by this authors on morbidly obese patients submitted to a gastric bypass demonstrated a similar variation in these parameters ${ }^{1}$. Similar results have been seen in other studies $^{3,10,11}$.

CRP presents an increase in concentration which peaks on the $3^{\text {rd }}$ day and then decreases by the $5^{\text {th }}$ day. In a Japanese study, 20 patients with advanced gastric cancer submitted to total gastrectomy and broad lymphadenectomy, had their CRP concentration monitored after surgery. No significant increase was observed with the peak occurring on the $3^{\text {rd }} P O D$ after which values gradually decreased ${ }^{10}$. However, cancer patients are known to have higher concentrations of CRP when compared to healthy subjects or patients suffering from benign diseases ${ }^{4}$. Tumor growth may cause a peritumoral inflammatory growth and thus increase CRP values ${ }^{3,5,7}$. Furthermore, CRP may be an indicator of immunological response to the tumor ${ }^{4}$.

It has been well documented that chronic illnesses such as gastric cancer are associated with a permanent and constant inflammatory state which can be corroborated by the increase of other inflammatory markers such as interleukin 6, and the tumoral necrosis factor ${ }^{12}$. After complex surgeries, the values increase and peak after two or three days followed by a sharp decrease. A spike in CRP values on the $2^{\text {nd }}$ and $3^{\text {rd }}$ POD after major orthopedic surgery has also been demonstrated; however, an additional increase over a period of one or two weeks suggests the presence of a serious complication ${ }^{13}$. In another study referring to patients who suffered from complications after being submitted to surgery with similar characteristics, an increase in CRP was observed 106 hours after the procedure with a mean of more than 100 $\mathrm{mg} / \mathrm{l}$, comparable to a patient with sepsis ${ }^{14}$.In a recent article assessing CRP behavior in 100 patients submitted to elective orthopedic surgery, Orrego et al. described a significant peak 2 or 3 days after surgery, with normal values obtained approximately 30 days after surgery².

In this study, as able to measure these values only up to five days after surgery since the patient is usually discharged on the $7^{\text {th }}$ POD.

\section{CONCLUSION}

It is important to precisely understand the behavior of these inflammatory parameters ( $C B C$ and $C R P)$ which are induced by an elective complex surgery and expected in the course of "normal" postoperative evolution, and that it be routinely monitored in order to determine an abnormal response and prematurely detect complications or infection.

\section{REFERENCES}

1. Csendes A., Burgos AM, Roizblatt D, Garay C, Bezama P, Inflammatory Response Measured By Body Temperature, C-Reactive Protein and White Blood Cell Count 1, 3, and 5 Days After Laparotomic or Laparoscopic Gastric Bypass Surgery. OBES SURG 2009; 19:890-893

2. Orrego $M$, Perez $M$, Perez $M$, Jorge $C$, Mardones $R$, Valores plasmáticos de proteína $C$ reactiva $(P C R)$ en cirugía ortopédica electiva, RevMéd Chile 2005; 133: 1341-1348

3. Kim D, Yong Oh S, Chan H, Lee S, Kwon K, Kim B, et al, Clinical significances of preoperative serum interleukin- 6 and $C$-reactive protein level in operable gastric cancer, BMC Cancer 2009; 9-155:1-9

4. Heikkila K, Ebrahim S, Lawlor A, A systematic review of the association between circulating concentrations of $C$ reactive protein and cancer, Epidemiol Community Health

2007; 61:824-832.

5. Cánovas N, Vera M, Candia R, Astroza G, Baksai K, Messenger $K$, Proteína $C$ reactiva como predictor de complicaciones postoperatorias en apendicitis aguda Rev. Chilena de Cirugía. 2003; 55-6, 628-630

6. Csendes A, Braghetto I, Díaz J, Castillo J, Rojas J, Cortés S, Morbilidad y mortalidad operatoria de la gastrectomía subtotal y total por cáncer gástrico 2004 a 2010. Parte I de un estudio prospectivo, Rev. Chilena de Cirugía, 2011; 63: 585-590

7. Ministerio de salud. Guía clínica Cáncer Gástrico. Santiago: Minsal, 2010.

8. Crumley A, McMillan D, McKernan M, Going J, Shearer C, Stuart $\mathrm{R}$, An elevated C-reactive protein concentration, prior to surgery, predicts poor cancer-specific survival in patients undergoing resection for gastro-oesophageal cancer, British Journal of Cancer 2006; 94:1568 - 1571

9. Torregroza M, Guarnizo C, Enfoque terapéutico del cáncer gástrico. Revisión de la literatura, RevColombCanCeRol 2011; 15: 30-39

10. Shito M, Ueda M, Wakabayashi G, Endo M, Kitajima M. Pathophysiological response of cytokines and vasoactive agents in patients undergoing total gastrectomy. Eur J Surg 1998; 164 $115-118$

11. Okafor B, Maclellan G, Postoperative changes of erythrocyte sedimentation rate, plasma viscosity and $C$ - reactive protein levels after hip surgery, ActaorthopedicaBelgica 1998; 64-1: 52-56

12. Ohzato $\mathrm{H}$, Yoshizaki $\mathrm{K}$, Nishimoto $\mathrm{N}$, Ogata A, Tagoh $\mathrm{H}$, Monden $M$, et al. Interleukin- 6 as a new indicator of inflammatory status: detection of serum levels of interleukin-6 and C-reactive protein after surgery. Surgery 1992; 111: 201-209.

13. Niskanen R, Korkala O, Pammo H, Serum C-Reactive Protein levels after total hip and knee arthroplasty, J Bone Joint Surg1996;78-B:431-3.

14. Kragsbjerg $P$, Holmberg $H$, Vikerfors $T$, Serum concentrations of interleukin-6, tumour necrosis factor-alpha, and C-reactive protein in patients undergoing major operations. Eur J Surg. 1995; 161:17-22. 